University of Nebraska - Lincoln

DigitalCommons@University of Nebraska - Lincoln

1953

\title{
Streptomyces leidnematis n. sp., Growing on Two Species of Nematodes of the Cockroach
}

\author{
Glenn L. Hoffman \\ US Fish and Wildlife Service
}

Follow this and additional works at: https://digitalcommons.unl.edu/usfwspubs

Part of the Aquaculture and Fisheries Commons

Hoffman, Glenn L., "Streptomyces leidnematis n. sp., Growing on Two Species of Nematodes of the Cockroach" (1953). US Fish \& Wildlife Publications. 120.

https://digitalcommons.unl.edu/usfwspubs/120

This Article is brought to you for free and open access by the US Fish \& Wildlife Service at DigitalCommons@University of Nebraska - Lincoln. It has been accepted for inclusion in US Fish \& Wildlife Publications by an authorized administrator of DigitalCommons@University of Nebraska - Lincoln. 


\title{
STREPTOMYCES LEIDNEMATIS N. SP., GROWING ON TWO SPECIES OF NEMATODES OF THE COCKROACH
}

\author{
GLenn L. Hoffman
}

University of North Dakota

In $1948 \mathrm{Mr}$. J. R. Wennemark called the writer's attention to a filamentous growth extending from the cuticle of Leidynema appendiculata and Hammerschmidtiella diesingi, oxyurid nematodes found in the intestine of the American roach, Periplaneta americana, which was collected in Iowa City, Iowa. Because of the extreme filamentous accumulation it was thought to be the mycelium of a fungus. Further observation on material from roaches reared in Grand Forks, North Dakota, and Detroit, Michigan, showed that the organism was not fungus but a member of the Actinomycetaceae. Slides were sent to Profs. R. S. Breed and H. J. Conn who agreed that the organism belonged in that group and suggested that it be placed in the genus Streptomyces. Dr. Lyell Thomas (1952) observed a filamentous organism which was not a fungus, growing on the cuticle of an oxyurid nematode in frogs. Leidy (1849) and Thomas (1930) have recorded the only known fungus, Enterobrus sp., on nematodes.

\section{Streptomyces leidynematis n. sp.}

All attempts to culture the organism on nutrient agar, cockroach cuticle agar, and Ascaris cuticle agar, both aerobically and anaerobically failed. Because of this the present descriptions are made only on a morphological and habitat basis. 
Mycelium: Gram positive. Not acid-fast. Hyphae approximately $0.7 \mu$ in diameter and up to $280 \mu$ in length. Very little branching. Fragmentation of hyphae into elements approximately $3-4 \mu$ long (Fig. 2). Hyphae not spirally twisted.

Conidia (Fig. 2): Approximately $2.1 \mu$ long by $1 \mu$ wide. Acid fast. Two and eight-tenths to $4.2 \mu$ between conidia.

Habitat: Growing on the cuticle of the cockroach nematodes, Leidynema appendiculata and Hammerschmidtiella diesingi. The streptomycete is named after L. appendiculata because more of them were infected than $H$. diesingi.

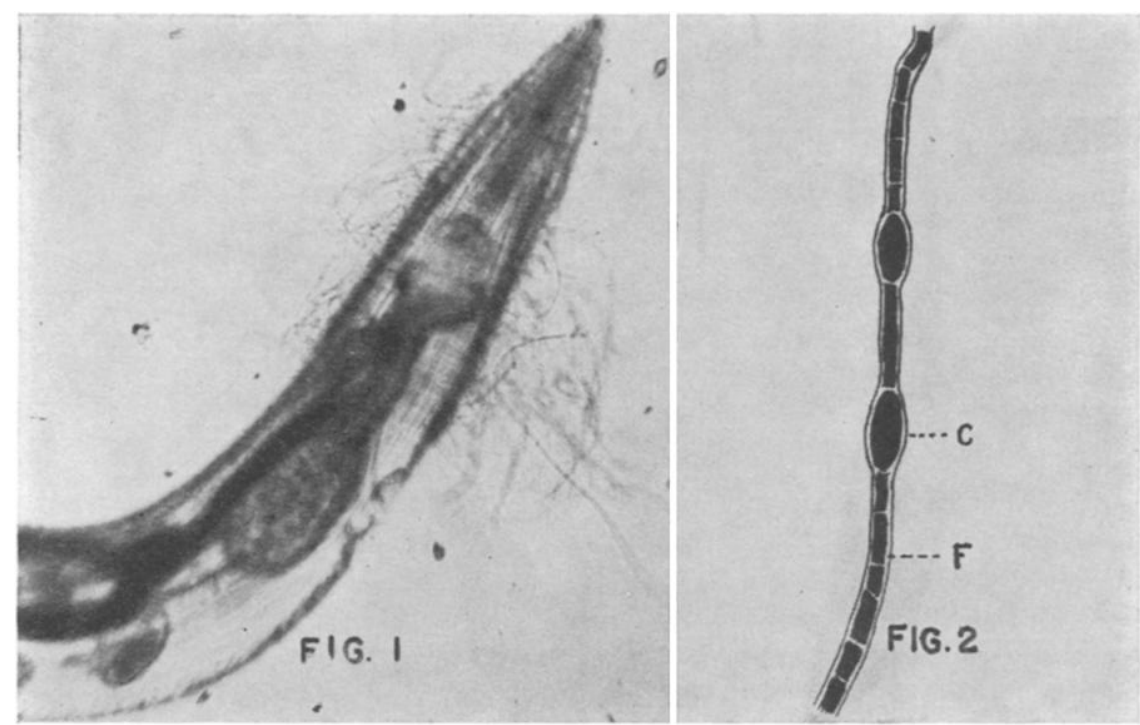

FIG. 1. Photomicrograph of an oxyurid nematode of the roach infected with Streptomyces leidynematis $\mathrm{n}$. $\mathrm{sp}$.

FIG. 2. Free hand drawing of a Gram stained filament of S. leidynematis n. sp. $\mathrm{C}=$ conida, $\mathrm{F}=$ fragmented hypha.

\section{Relationship of the Streptomycete to the Nematode}

There was no evidence that the bacterium had any ill effects on the nematode although some were literally covered with a blanket of the growth (Fig. 1). Cross sections of heavily infected nematodes stained with Mallory's phloxine-methylene blue stain failed to reveal any growth of the organism through the worm cuticle. Also, no holdfast organs of of any type could be seen. It appears that the organism utilizes the nematode for anchorage but probably derives its metabolic needs from the intestinal contents of the roach. Apparently it is very specific in its habitat requirement because all culture attempts failed. Large tufts of the mycelium were placed in small Petri dishes containing many living Trichinella larvae in $0.85 \%$ three salt Ringer's solution and there was no evidence of growth on the larvae during three months of observation. 
All of the roaches examined were reared in laboratory cages where reinfection with the nematode was probably optimum resulting in a higher rate of infection than the $83.5 \%$ reported by Dobrovolny and Ackert (1934) in wild adult roaches. Of 53 adult roaches examined in the present study, all were infected except one. The North Dakota roaches were less heavily infected with the streptomycete. Of 46 roaches from North Dakota 45 were infected with a total of 192 adult nematodes ranging from 1 to 19 with an average of 4.17 per roach. Of the total 35 (18\%) were infected with the streptomycete. Twelve $(6 \%)$ of the roaches harbored infected nematodes.

All eleven adult roaches from Michigan were infected having a total of 212 adult nematodes ranging from 1 to 59 with an average of 19.1 per roach. Of these 212 nematodes, $145(68.4 \%)$ were infected with the streptomycete. All roaches harbored infected nematodes.

Apparently the larval nematodes become infected soon after becoming established in the hind gut of the roach. Of 51 half grown larvae from infected roaches, $33(61 \%)$ were infected and of 33 younger larvae (238 to $280 \mu$ long) $15(45 \%)$ were infected. No evidence of this streptomycete was observed in three lots of embryonated ova from infected nematodes kept under observation for 3 months. It therefore seems unlikely that any spore of the organism is transovarial in the infected nematode.

The author wishes to thank Mrs. Carolyn W. Hoffman for technical assistance; the Misses Barbara Gretter and Grace Campbell and Mr. John Vennes for the use of roaches reared in Dr. R. G. Fischer's laboratory; Profs. R. S. Breed, H. J. Conn and E. A. Steinhaus for helpful suggestions and reading the manuscript; and the Gulf Oil Company Research Laboratories for roaches used.

\section{References Cited}

Dobrovolny, C. G., and Ackert, J. E. 1934. The life history of Leidynema appendiculata (Leidy), a nematode of cockroaches. Parasitology, Cambridge (Eng.), 26: 468-480.

LEIDY, JosePH. 1849. On the existence of Entophyta in healthy animals as a natural condition. Proc. Acad. Nat. Sci. Phila. 4: 225-333.

Thomas, Lyell. 1930. Rhigonema nigella spec. nov., a nematode and its plant commensal, Enterobrus sp? from the milliped. J. Parasitology 17: 30-34.

Thomas, Lyell. 1952. Personal communication. 